\title{
Applying an educational theory to effectively teach nursing practice and NCLEX categories
}

\author{
Karen M. Myrick \\ Quinnipiac University, Hamden, Connecticut, United States \\ Correspondence: Karen M. Myrick. Adress: 275 Mount Carmel Avenue, NH 400L, Hamden, Ct, 06518, USA. Email: \\ karen.myrick@quinnipiac.edu.
}

Received: July 2, 2012

DOI : $10.5430 /$ jnep.v3n3p124
Accepted: August 26, $2012 \quad$ Online Published: November 22, 2012

URL: http://dx.doi.org/10.5430/jnep.v3n3p124

\section{Abstract}

There is a desire amongst nursing faculty to effectively teach the process of nursing, and to have a meaningful context in which to disseminate this information. The use of an educational theory as a guide to nursing faculty in teaching the practice of nursing, specifically the NCLEX categories is demonstrated.

Applying the ARCS Motivational Theory to the teaching of nursing practice using the NCLEX categories as a format is a way to demonstrate the categories, process, and relevance of the model. The separate categories of the NCLEX are outlined and addressed.

\section{Key words}

Teaching efficacy, NCLEX, Pedagogy

\section{Purpose}

To demonstrate how an educational theory can be used to teach nursing, specifically the NCLEX categories that undergraduate nursing students must master. Keller, an instructional researcher used a number of theories to create an instructional design model for motivation, the ARCS Model. The model has 4 components, Attention, Relevance, Confidence and Satisfaction. These components make the model an appropriate method in which instructors can teach, and students will learn, the NCLEX categories.

\section{I ntroduction}

Nursing faculty strive to present their material in a meaningful and in an operative fashion. John Keller developed and introduced the ARCS (Attention, Relevance, Confidence, and Satisfaction) Motivation Theory. His theory includes the Motivational Model, which is used to analyze the motivational problem, design motivational strategies, implement those strategies and evaluate consequences ${ }^{[1]}$. The ARCS Motivation Theory includes the four major motivational categories of strategy, including attention, relevance, confidence and satisfaction ${ }^{[2]}$. Attention includes perceptual arousal, inquiry arousal, and variability. Relevance includes familiarity, goal orientation, and motive matching. Confidence embraces expectancy for success, and attribution molding. 
Applying the ARCS Motivational Theory to the teaching of nursing practice using the NCLEX categories as a format is a way to demonstrate the categories, process, and relevance of the model. It has been stated that the ARCS Motivation Theory is beneficial in directing the mental map of students for better knowledge construction ${ }^{[3]}$. That stated, this process is well suited for use in teaching nursing practice. The importance of directing a student nurses' learning to improve knowledge construction will be beneficial to mastering the NCLEX categories. Studies have shown that utilizing the ARCS Motivational Theory has been beneficial in that the training utilizing the theory allowed participants to make significant gains in content knowledge, and feedback indicated that high levels of satisfaction occurred with the use of the theory ${ }^{[4]}$.

The ARCS model is appropriate for nursing instructors to use to teach nursing students, as the categories of the theory help both instructor to teach, and student to learn the categories of NCLEX. I have used the ARCS model to delineate the NCLEX categories (Safe Effective Care Environment, Management of Care, Safety and Infection Control, Health Promotion and Maintenance, and Psychosocial Integrity), and to then teach students using each of the components of the model. By using the ARCS model, I was able to promote learning through categorizing the course content to reflect the components of the theory. The course objectives were easily defined to demonstrate outcomes consistent with mastery of the NCLEX categories.

The following tables demonstrate each component of the theory, matched with each NCLEX category, and provides an example of how the instructor can effectively teach each NCLEX category by using the theory.

Table 1-1. Each component of the theory matched with each NCLEX category

\begin{tabular}{|c|c|c|c|c|c|}
\hline \multirow{2}{*}{$\begin{array}{l}\text { Motivational } \\
\text { Theory } \\
\text { Categories }\end{array}$} & \multicolumn{5}{|c|}{ NCLEX Categories } \\
\hline & $\begin{array}{l}\text { Safe Effective } \\
\text { Care Environment }\end{array}$ & $\begin{array}{l}\text { Management } \\
\text { Of Care }\end{array}$ & $\begin{array}{l}\text { Safety and } \\
\text { Infection Control }\end{array}$ & $\begin{array}{l}\text { Health Promotion } \\
\text { And Maintenance }\end{array}$ & $\begin{array}{l}\text { Psychosocial } \\
\text { Integrity }\end{array}$ \\
\hline Attention & $\begin{array}{l}\text { An instructor can teach } \\
\text { this category through } \\
\text { increasing perceptual } \\
\text { arousal by utilizing } \\
\text { novel events in } \\
\text { instruction. An example } \\
\text { may be creating a } \\
\text { simulation of } 5 \text { unsafe } \\
\text { items in a patient care } \\
\text { setting and asking the } \\
\text { student to find them and } \\
\text { note why they are } \\
\text { unsafe. }\end{array}$ & $\begin{array}{l}\text { Through inquiry } \\
\text { arousal, the } \\
\text { instructor can } \\
\text { encourage students } \\
\text { to generate } \\
\text { management of care } \\
\text { questions and } \\
\text { problems to solve. }\end{array}$ & $\begin{array}{l}\text { Using variability, the } \\
\text { instructor can demonstrate } \\
\text { safety and infection control } \\
\text { with such measures as } \\
\text { video presentations of } \\
\text { safety measures, } \\
\text { microbiology slides of } \\
\text { infections, utilizing } \\
\text { MMWR reports, and } \\
\text { hospital data. }\end{array}$ & $\begin{array}{l}\text { Use inquiry arousal and } \\
\text { have the learner generate } \\
\text { problem solving, } \\
\text { addressing a health } \\
\text { promotion and } \\
\text { maintenance problem } \\
\text { through a presentation to } \\
\text { describe the problem and } \\
\text { their solution to the } \\
\text { problem. }\end{array}$ & $\begin{array}{l}\text { Through inquiry arousal, } \\
\text { pose questions relating } \\
\text { to maintaining patients } \\
\text { psychosocial integrity in } \\
\text { various clinical } \\
\text { scenarios. }\end{array}$ \\
\hline Relevance & $\begin{array}{l}\text { Using familiarity to } \\
\text { drive home a concrete } \\
\text { example would help to } \\
\text { teach this category. } \\
\text { Example: showing a } \\
\text { medication } \\
\text { administration list with } \\
\text { two patient names that } \\
\text { are very similar, and } \\
\text { medications that are } \\
\text { strikingly different. }\end{array}$ & $\begin{array}{l}\text { Utilizing goal } \\
\text { orientation, the } \\
\text { instructor can } \\
\text { present goals and } \\
\text { have the learner } \\
\text { define those goals } \\
\text { for the management } \\
\text { of a particular } \\
\text { patient care } \\
\text { scenario. }\end{array}$ & $\begin{array}{l}\text { Using familiarity and } \\
\text { relating a safety and } \\
\text { infection control scenario } \\
\text { to the students clinical } \\
\text { placements or experiences } \\
\text { would be a good way to } \\
\text { teach this category. }\end{array}$ & $\begin{array}{l}\text { Using motive matching, } \\
\text { have the students choose a } \\
\text { health promotion and } \\
\text { maintenance problem that } \\
\text { they feel passionate about, } \\
\text { and have them prepare a } \\
\text { report in which they } \\
\text { develop a mechanism to } \\
\text { assist with the problem. }\end{array}$ & $\begin{array}{l}\text { Using familiarity, adapt } \\
\text { instruction to provide } \\
\text { examples of how } \\
\text { psychosocial integrity } \\
\text { can be compromised. } \\
\text { An example would be } \\
\text { violation of HIPPA } \\
\text { regulations and } \\
\text { disclosure of a patients' } \\
\text { cancer or HIV status, } \\
\text { and the psychosocial } \\
\text { effects that may result. }\end{array}$ \\
\hline
\end{tabular}


Table 1-1. (continued)

\begin{tabular}{|c|c|c|c|c|c|}
\hline \multirow{2}{*}{$\begin{array}{l}\text { Motivational } \\
\text { Theory } \\
\text { Categories }\end{array}$} & \multicolumn{5}{|c|}{ NCLEX Categories } \\
\hline & $\begin{array}{l}\text { Safe Effective } \\
\text { Care Environment }\end{array}$ & $\begin{array}{l}\text { Management } \\
\text { Of Care }\end{array}$ & $\begin{array}{l}\text { Safety and } \\
\text { Infection Control }\end{array}$ & $\begin{array}{l}\text { Health Promotion } \\
\text { And Maintenance }\end{array}$ & $\begin{array}{l}\text { Psychosocial } \\
\text { Integrity }\end{array}$ \\
\hline Confidence & $\begin{array}{l}\text { Through attribution } \\
\text { molding, the } \\
\text { instructor can use the } \\
\text { ARCS Motivation } \\
\text { Theory to provide } \\
\text { feedback which } \\
\text { supports the } \\
\text { students' ability and } \\
\text { effort in learning } \\
\text { about safe and } \\
\text { effective care } \\
\text { environments. }\end{array}$ & $\begin{array}{l}\text { Through expectancy } \\
\text { of success, the } \\
\text { instructor can make } \\
\text { the learner aware of } \\
\text { the performance } \\
\text { requirements and } \\
\text { evaluative criteria } \\
\text { necessary for a } \\
\text { patient management } \\
\text { of care situation. }\end{array}$ & $\begin{array}{l}\text { Provide direct } \\
\text { feedback to students } \\
\text { on their infection } \\
\text { control and patient } \\
\text { safety skills. } \\
\text { Observe and } \\
\text { comment on hand } \\
\text { washing techniques, } \\
\text { patient education } \\
\text { and safety measures. }\end{array}$ & $\begin{array}{l}\text { With attribution } \\
\text { molding, provide } \\
\text { feedback to students } \\
\text { that support their } \\
\text { success. With } \\
\text { presentations, provide } \\
\text { feedback to the process } \\
\text { and feasibility of } \\
\text { proposed health } \\
\text { promotion and } \\
\text { maintenance measures. }\end{array}$ & $\begin{array}{l}\text { Using expectancy of success, } \\
\text { make the students aware of } \\
\text { performance requirements } \\
\text { and evaluative criteria } \\
\text { necessary for dealing with } \\
\text { every patient and the } \\
\text { maintenance of the integrity } \\
\text { of their psychosocial selves. } \\
\text { Look for a plan for this in } \\
\text { each care plan the student } \\
\text { develops. }\end{array}$ \\
\hline Satisfaction & $\begin{array}{l}\text { Using the theory and } \\
\text { natural } \\
\text { consequences, an } \\
\text { instructor can } \\
\text { provide the } \\
\text { opportunity for the } \\
\text { student to use their } \\
\text { newly acquired } \\
\text { knowledge to "fix" } \\
\text { the simulated } 5 \\
\text { patient care setting } \\
\text { unsafe items. }\end{array}$ & $\begin{array}{l}\text { Incorporate equity, } \\
\text { teach nursing } \\
\text { practice regarding } \\
\text { the category of } \\
\text { management of care } \\
\text { by maintaining } \\
\text { consistent standards } \\
\text { and consequences } \\
\text { for task } \\
\text { management. }\end{array}$ & $\begin{array}{l}\text { Use natural } \\
\text { consequences and } \\
\text { provide } \\
\text { opportunities in both } \\
\text { simulated and real } \\
\text { patient care } \\
\text { situations for } \\
\text { students to } \\
\text { demonstrate their } \\
\text { infection control and } \\
\text { patient safety } \\
\text { measures. }\end{array}$ & $\begin{array}{l}\text { Provide opportunity } \\
\text { for use of new skills, } \\
\text { allowing the } \\
\text { opportunity for } \\
\text { students to speak at } \\
\text { local community } \\
\text { centers or hospitals or } \\
\text { other appropriate } \\
\text { setting to promote a } \\
\text { health promotion and } \\
\text { maintenance issue. }\end{array}$ & $\begin{array}{l}\text { With equity, maintain } \\
\text { consistent standards for task } \\
\text { accomplishment. Example: } \\
\text { look for or ask for the } \\
\text { psychosocial component of } \\
\text { each patient care plan the } \\
\text { students present. }\end{array}$ \\
\hline
\end{tabular}

Table 1-2. Each component of the theory matched with each NCLEX category

\begin{tabular}{|c|c|c|c|c|c|}
\hline \multirow{2}{*}{$\begin{array}{l}\text { Motivational } \\
\text { Theory } \\
\text { Categories }\end{array}$} & \multicolumn{5}{|c|}{ NCLEX Categories } \\
\hline & $\begin{array}{l}\text { Physiologic } \\
\text { Integrity }\end{array}$ & $\begin{array}{l}\text { Basic Care } \\
\text { And Comfort }\end{array}$ & $\begin{array}{l}\text { Pharmacologic and } \\
\text { Parenteral Therapy }\end{array}$ & $\begin{array}{l}\text { Reduction of } \\
\text { Risk Potential }\end{array}$ & $\begin{array}{l}\text { Physiologic } \\
\text { Adaptation }\end{array}$ \\
\hline Attention & $\begin{array}{l}\text { Use variability in } \\
\text { teaching methods and } \\
\text { instruction. Show the } \\
\text { outcome of lack of } \\
\text { physiologic integrity } \\
\text { maintenance in various } \\
\text { situations, such as the } \\
\text { operating room, and } \\
\text { outpatient diabetes } \\
\text { clinic. }\end{array}$ & $\begin{array}{l}\text { Use perceptual } \\
\text { arousal to draw } \\
\text { attention to } \\
\text { scenarios where } \\
\text { patients' basic } \\
\text { care and comfort } \\
\text { have been } \\
\text { neglected. }\end{array}$ & $\begin{array}{l}\text { Use variability to } \\
\text { demonstrate the } \\
\text { concepts behind both } \\
\text { pharmacologic and } \\
\text { parenteral therapy. } \\
\text { One method may be to } \\
\text { use video and } \\
\text { simulation, as well as } \\
\text { to use tables and } \\
\text { medication } \\
\text { administration records. }\end{array}$ & $\begin{array}{l}\text { Adapt an inquiry } \\
\text { arousal through posing } \\
\text { questions to solve } \\
\text { relating to risk } \\
\text { potential in various } \\
\text { patient care scenarios. }\end{array}$ & $\begin{array}{l}\text { Use perceptual arousal by } \\
\text { utilizing novel events in } \\
\text { teaching such as } \\
\text { simulation, demonstration } \\
\text { of what can occur within } \\
\text { physiologic adaptation in a } \\
\text { variety of patient settings. }\end{array}$ \\
\hline Relevance & $\begin{array}{l}\text { Utilizing goal } \\
\text { orientation, Provide } \\
\text { objectives which } \\
\text { outline the relevance of } \\
\text { physiologic integrity to } \\
\text { each objective. }\end{array}$ & $\begin{array}{l}\text { Adapt instruction } \\
\text { to use concrete } \\
\text { language and } \\
\text { provide examples } \\
\text { of concepts that } \\
\text { are related to the } \\
\text { students' } \\
\text { experiences. }\end{array}$ & $\begin{array}{l}\text { Using motive } \\
\text { matching, attempt to } \\
\text { use teaching strategies } \\
\text { that match the motive } \\
\text { profiles of the students. } \\
\text { Avoidance of } \\
\text { pharmacologic errors } \\
\text { is an example which } \\
\text { should motivate the } \\
\text { group. }\end{array}$ & $\begin{array}{l}\text { Adapt instruction to } \\
\text { use examples that } \\
\text { demonstrate risk } \\
\text { reduction related to } \\
\text { students experiences. }\end{array}$ & $\begin{array}{l}\text { Use goal orientation, and } \\
\text { provide written goals for } \\
\text { physiologic adaptation. }\end{array}$ \\
\hline
\end{tabular}


Table 1-2. (continued)

\begin{tabular}{|c|c|c|c|c|c|}
\hline \multirow{2}{*}{$\begin{array}{l}\text { Motivational } \\
\text { Theory } \\
\text { Categories }\end{array}$} & \multicolumn{5}{|c|}{ NCLEX Categories } \\
\hline & $\begin{array}{l}\text { Physiologic } \\
\text { Integrity }\end{array}$ & $\begin{array}{l}\text { Basic Care } \\
\text { And Comfort }\end{array}$ & $\begin{array}{l}\text { Pharmacologic and } \\
\text { Parenteral Therapy }\end{array}$ & $\begin{array}{l}\text { Reduction of } \\
\text { Risk Potential }\end{array}$ & $\begin{array}{l}\text { Physiologic } \\
\text { Adaptation }\end{array}$ \\
\hline Confidence & $\begin{array}{l}\text { Through attribution } \\
\text { molding, provide } \\
\text { feedback to students } \\
\text { that promotes their } \\
\text { confidence when } \\
\text { working with } \\
\text { physiologic integrity } \\
\text { patient issues. }\end{array}$ & $\begin{array}{l}\text { Make the students } \\
\text { aware of the } \\
\text { performance } \\
\text { requirements for } \\
\text { patient issues of } \\
\text { care and comfort. } \\
\text { Instill confidence } \\
\text { by providing } \\
\text { evaluative criteria. }\end{array}$ & $\begin{array}{l}\text { Using attribution } \\
\text { molding, provide } \\
\text { feedback for students } \\
\text { with pharmacologic } \\
\text { and parenteral therapy } \\
\text { regimens and their } \\
\text { sequelae to support } \\
\text { students' abilities. }\end{array}$ & $\begin{array}{l}\text { Provide students with } \\
\text { performance } \\
\text { requirements and } \\
\text { evaluative criteria to } \\
\text { assist with their } \\
\text { expectancy of success. }\end{array}$ & $\begin{array}{l}\text { Provide challenge setting, } \\
\text { through giving multiple } \\
\text { levels of achievement. This } \\
\text { will allow students to set } \\
\text { their own personal goals or } \\
\text { standards of } \\
\text { accomplishment. }\end{array}$ \\
\hline Satisfaction & $\begin{array}{l}\text { Utilizing equity, } \\
\text { maintain consistent } \\
\text { standards for task } \\
\text { accomplishment } \\
\text { regarding patient } \\
\text { issues of physiologic } \\
\text { integrity. }\end{array}$ & $\begin{array}{l}\text { For basic care and } \\
\text { comfort patient } \\
\text { care related tasks, } \\
\text { use natural } \\
\text { consequences, and } \\
\text { provide } \\
\text { opportunities to } \\
\text { use newly } \\
\text { acquired skills in } \\
\text { clinical and } \\
\text { simulation lab. }\end{array}$ & $\begin{array}{l}\text { Employ positive } \\
\text { consequences and } \\
\text { provide feedback that } \\
\text { will reinforce or } \\
\text { sustain desired } \\
\text { behaviors with regards } \\
\text { to items in this realm of } \\
\text { patient care. }\end{array}$ & $\begin{array}{l}\text { To teach the category } \\
\text { of risk reduction } \\
\text { potential, using the } \\
\text { motivational category } \\
\text { of satisfaction, use } \\
\text { equity to maintain } \\
\text { consistent standards. }\end{array}$ & $\begin{array}{l}\text { Use positive consequences } \\
\text { to give feedback that will } \\
\text { sustain or reinforce the } \\
\text { desired nursing behaviors. }\end{array}$ \\
\hline
\end{tabular}

\section{Summary}

John Keller's ARCS Motivation Theory is an effective instructional theory ${ }^{[5]}$. Teaching the NCLEX categories utilizing this theory will be both effective and educational. Nursing faculty continually strive to find effective pedagogy. Using theories outside of nursing, but related to education and motivation may be additionally beneficial. The theory is adaptable and applicable for the NCLEX categories as demonstrated here.

\section{References}

[1] Marovitz, M. E., \& Buckley, J. Integrating ARCS motivational theory into the component display theory of instructional design. 1987.

[2] Faryadi, Q. Instructional design models: What a revolution! Online Submission. 2007.

[3] Faryadi, Q., Bakar, Z. A., Maidinsah, H., \& Muhamad, A. Redefining classroom culture through instructional design Online Submission. 2007.

[4] Ross, J. D., Thigpin, C., Cavalluzzo, L., Guzman, J., Patterson, L., \& AEL, Inc., Charleston,WV. Reading teachers first: Statewide implementation of ePDAEL. 2004.

[5] Keller, J.M. Motivational Design of Instruction. In C Reiglutin (ed), Instructional Design Theories and Models: An Overview of Their Current Status. Hillsdale, N.J.: Erlbaum, 1983. 